\title{
Meningkatkan Kemampuan Kosakata Anak Usia Dini Melalui Media Wayang Papercraft
}

\section{Mirawati Dina Lestariningsih ${ }^{*}$, Desak Putu Parmiti2}

${ }_{1}$ Pendidikan Guru Pendidikan Anak Usia Dini, Universitas Pendidikan Ganesha, Singaraja, Indonesia

2 Teknologi Pendidikan, Universitas Pendidikan Ganesha, Singaraja, Indonesia

\section{ART I C L E I N F O}

Article history:

Received 27 January 2021

Revised 15 February 2021

Accepted 01 April 2021

Available online 29 April 2021

Kata Kunci:

Media Wayang, Papercraft,

Kosa Kata

Keywords:

Puppet Media, Papercraft,

Vocabulary

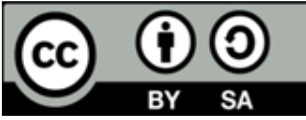

This is an open access article under the CC BY-SA license.

Copyright (C) Universitas Pendidikan Ganesha. All rights reserved.

\begin{abstract}
A B S T R A K
Rendahnya kosakata pada anak usia dini, yang disebabkan oleh kurangnya media pembelajaran yang dapat memfasilitasi siswa dalam belajar. Tujuan penelitian ini yaitu untuk mengembangkan media wayang papercraft unuk meningkatkan kemampuan kosakata pada anak usia dini. Jenis penelitian ini adalah penelitian dan pengembangan (Research and Development) dengan menggunakan model ADDIE. Subjek pada penelitian ini berjumlah 4 orang ahli. Teknik yang digunakan dalam mengumpulkan data pada penelitian ini yaitu wawancara, observasi, dan anget. Instrumen yang digunakan dalam mengumpulkan data yaitu kuesioner. Teknik yang digunakan untuk menganalisis data yaitu analisis kualitatif dan kuantitatif. Hasil penelitian ini yaitu hasil penilaian yang dilakukan oleh ahli materi pembelajaran terhadap media yang dikembangkan dalam kategori valid dan ahli media pembelajaran juga mendapatkan kategori valid. Dapat disimpulkan bahwa media wayang papercraft yang telah dikembangkan layak dan dapat untuk diterapkan dalam proses pembelajaran. Implikasi penelitian ini yaitu media yang dikembangkan dapat digunakan oleh guru sebagai fasilitas belajar siswa sehingga dapat meningkatkan kemampuan kosakata pada siswa usia dini.
\end{abstract}

\section{A B S T R A C T}

The low vocabulary in early childhood, which is caused by the lack of learning media that can facilitate students in learning. The purpose of this study is to develop papercraft puppet media to improve vocabulary skills in early childhood. This type of research is research and development (Research and Development) using the ADDIE model. Subjects in this study amounted to 4 experts. The techniques used in collecting data in this study were interviews, observation, and anget. The instrument used in collecting data is a questionnaire. The technique used to analyze the data is qualitative and quantitative analysis. The results of this study are the results of the assessment carried out by learning material experts on the media developed in the valid category and learning media experts also get a valid category. It can be concluded that the papercraft puppet media that has been developed is feasible and can be applied in the learning process. The implication of this research is that the developed media can be used by teachers as student learning facilities so that they can improve vocabulary skills in early childhood students.

\section{Pendahuluan}

Salah satu tujuan pendidikan anak usia dini yaitu mengembangkan pribadi anak serta kemampuan kognitif, sosial, bahasa, emosional, mototik, agama, seni dan moral (Darihastining, Aini, Maisaroh, \& Mayasari, 2020; Ruiyat, Yufiarti, \& Karnadi, 2019b). Meningkatkan kognitif serta pembentukan kepribadian anak usia dini dapat ditumbuhkan melalui pendidikan di sekolah. Tamankanak kanak merupakan salah satu pendidikan formal bagi anak usia dini (Marwiyati \& Istiningsih, 2021; Yuliani, Antara, \& Magta, 2017). Pembelajaran pada jenjang usia dini sangat berbeda dengan sekolah dasar. Pada jenjang PAUD aspek yang ditekankan yaitu aspek perkembangan (Fauziddin, 2015; Suwatra, Magta, \& Christiani, 2019). Perkembangan anak usia dini dari enam aspek yang saling mempengaruhi satu

Copyright (@) Universitas Pendidikan Ganesha. All rights reserved 
dengan yang lainnya. salah satunya yaitu aspek bahasa yang didalamnya terdiri dari kosakata (Akbar, 2015; Trisnanti, Tirtayani, \& Putra, 2018). Hal tersebut yang membuat aspek ini harus dikembangkan oleh guru. Aspek ini harus dikembangkan dengan optimal sehingga anak dapat melangkah ke jenjang selanjutnya. Salah satu aspek terpenting yang dikembangkan pada anak usia dini yaitu perkembangan bahasa, yang sangat dipengaruhi oleh kosakata (Susiani, Pudjawan, \& Renda, 2013; Triutami, Sudhita, \& Tegeh, 2014).

Penguasaan kosakata pada anak usia dini merupakan cerminan dari kemampuan berbicara (Liyana \& Kurniawan, 2019; Ruiyat, Yufiarti, \& Karnadi, 2019a). Pada usia 5 hingga 6 tahun kemampuan anak mengalami peningkatan, anak sudah dapat berbicara lancar dengan kosakata baru sekitar 8000 hingga 9000 kata (Pebriana, 2017; Suardi, Ramadhan, \& Asri, 2019). Kemampuan tersebut akan berkembang maksimal jika diberikan stimulus dari orangtua ataupun guru. Anak usia dini dapat mengembangkan kosakatanya degan proses menyerap arti baru setelah mendengarkan percakapan. Anak dapat mencari cara dalam memperbaiki kesalahpahaman, serta dapat belajar menjadi pendengar yang baik, perselisihan dengan temannya dapat diselesaikan dengan kata-kata dan mereka dapat bermain bersama. Walaupun anak usia dini mempunyai kuantitas kosakata yang baik, kosakata anak sedikit tercampuri oleh kosakata bahasa daerah. Kosakata anak dipengaruhi oleh lingkungan (Fika, Meilanie, \& Fridani, 2020; Ruiyat et al., 2019a). Semakin anak memiliki banyak kosakata, maka semakin banyak anak dapat memahami tuturan yang disampaikan oleh guru, orangtua, maupun temannya. Hal ini juga didukung oleh kunungan komunikasi yang baik antara orangtua dan anak sehingga hal ini berdampak pada kuantitas ragam kosakata yang dikuasi anak (Fadlilah, 2020; L. A. D. Putri, Yetti, \& Hartati, 2020). Pembelajaran yang terjadi di sekolah juga dapat membantu meningkatkan kosakata pada anak usia dini

Permasalahan yang terjadi saat ini yaitu rendahnya kosakata pada anak usia dini (Andriyani, Masrul, \& Fauziddin, 2018; Arifiyanti \& Ananda, 2018; Rosalina, Widyasari, Ismi, \& Hapsari, 2010). Permasalahan ini juga ditemukan pada salah satu taman kanak-kanak. Berdasarkan hasil observasi yang dilakukan di taman kanak-kanak gugus VI ditemukan permasalahan yakni kegiatan pembelajaran masih banyak kendala dan belum mencapai tingkat perkembangan kosakata pada anak. Saat proses pembelajaran dimulai, anak cenderung diam dan tidak mau mengemukakan pendapat secara sederhana. Selain itu saat kegiatan tanya jawab masih banyak anak yang bingung dalam memahami pertanyaan yang diberikan oleh guru. Saat bercerita dan menjelaskan cerita di depan kelas, rata-rata anak kesulitan dalam mengeluarkan kata-kata sehingga guru memancing anak agar seluruh siswa dapat bercerita. Saat proses pembelajaran berlangsung diharapkan seluruh anak ikut berpartisipasi sehingga dapat meningkatkan pemahaman anak (Cahyaningrum, Sudaryanti, \& Purwanto, 2017; Khadijah, Arlina, Hardianti, \& Maisarah, 2021). Permasalahan lainnya yang ditemukan yaitu kurangnya media pembelajaran yang dapat memotivasi siswa dalam belajar. Media yang digunakan bersifat monoton dan kurang menarik perhatian serta minat siswa dalam belajar. Media yang biasanya digunakan guru yaitu gambar pada lembar kerja siswa, sehingga masih banyak anak yang kurang memperhatikan guru saat mengajar. Hal ini menyebabkan anak tidak memahami materi yang diajarkan oleh guru sehingga anak memiliki kosakosakata yang rendah.

Berdasarkan permasalahan tersebut, maka salah satu cara untuk membantu meningkatkan kosakata pada anak usia dini yaitu dengan penggunaan media pembelajaran. Media pembelajaran dapat memudahkan siswa dalam memahami materi yang disampaikan oleh guru (Gunawan, Sahidu, Harjono, \& Suranti, 2017; Maqfiroh, Khutobah, \& Budyawati, 2020). Selain itu media pembelajaran juga dapat meningkatkan semangat serta motivasi siswa dalam belajar (Puspitorini, Subali, \& Jumadi, 2014; Sunismi, 2015; Zeptyani \& Wiarta, 2020). Media pembelajaran dapat membantu guru dalam memfasilitasi siswa belajar. Salah satu media yang dapat meningkatkan kosakata pada anak usia dini yaitu media pembelajaran wayang papercraft. Wayang merupakan cerita mengenai kebiasaan hidup serta tingkah laku manusia yang dimulai dari lahir, hidup, dan mati (Ayuswantana, Sachari, \& Irfansyah, 2020; Koesoemadinata, 2018). Wayang juga sebuah wiracerita yang mengisahkan kepahlawanan dari tokoh yang berwatak baik hingga berwatak Jahat (Suprihatin \& Pratamawati, 2019). Wayang merupakan media yang dapat digunakan untuk mengambarkan sebuah cerita kebiasaan hidup dan tingkah laku manusia yang diturunkan dari generasi ke genarasi. Kesenian ini diturunkan untuk mewariskan nilai etika, spiritalitas, falsafah hidup, dan estetika seni rupa (Alexander Nawangseto Mahendrapati, 2020; Nababan, Guntur, Mulyana, \& Dharsono, 2016).

Kelebihan dari media wayang ini yaitu dapat memudahkan anak dalam belajar, memberikan pengalaman lebih nyata, menarik perhatian anak, semua indra dapat diaktifkan (Devi \& Maisaroh, 2017; Pebri, Tegeh, \& Rahayu, 2017). Media wayang papercraft merupakan media pembelajaran berupa kerajinan tangan yang terbuat dari kertas sebagai medianya untuk membuat objek tiga dimensi. Pembuatan media ini dengan cara menggunting, melipat, hingga menempel pola yang sebelumnya telah didesain agar menjadi bentik yang diinginkan. Dan media tersebut nantinya akan dimainkan oleh guru. 
Langkah yang akan dilakukan dalam menerapkan media ini yaitu diawali dengan gruu mengucapkan salam dan bertanya seputar wayang, kemudian guru menjelaskan tokoh wayang dan mempersilahkan siswa untuk bertanya jika ada yang tidak dipahami, siswa mendengarkan guru bercerita, guru memberi kesempatan pada siswa untuk bertanya jawab, dan guru menyimpulkan pembelajaran. dapat disimpulkan bahwa pembelajaran seperti ini berbantuan media wayang dapat mengaktifkan siswa dalam belajar sehingga berdampak pada peningkatan penguasaan kosakata pada anak usia dini.

Penelitian sebelumnya mengenai media pembelajaran wayang menyatakan bahwa media pembelajaran dapat memudahkan siswa dalam memahami materi pelajaran (Putra, Handarini, \& Ramli, 2019). Temuan penelitian lainnya juga menyatakan bahwa media wayang dapat meningkatkan hasil belajar siswa (Salamah, 2017; Suswandari, 2019). Belum adanya penelitian mengenai media wayang papercraft membantu meningkatkan kemampuan kosakata pada anak usia dini. Tujuan penelitian ini adalah mengembangan media wayang papercraft unuk meningkatkan kemampuan kosakata pada anak usia dini. Diharapkan media pembelajaran wayang papercraft dapat membantu siswa dalam belajar sehingga dapat meningkatkan kemampuan kosakata pada anak usia dini.

\section{Metode}

Jenis penelitian ini yaitu pengembangan (Research and Development). Prosedur penelitian dan pengembangan ini menggunakan model ADDIE yang meliputi lima tahapan, yaitu analysis (analisis), design (desain), development (pengembangan), implementation (implementasi), dan evaluating (evaluasi) (Tegeh \& Kirna, 2010). Tahap implementasi dan evaluasi tidak dilakukan hal ini disebabkan karena situasi covid-19.

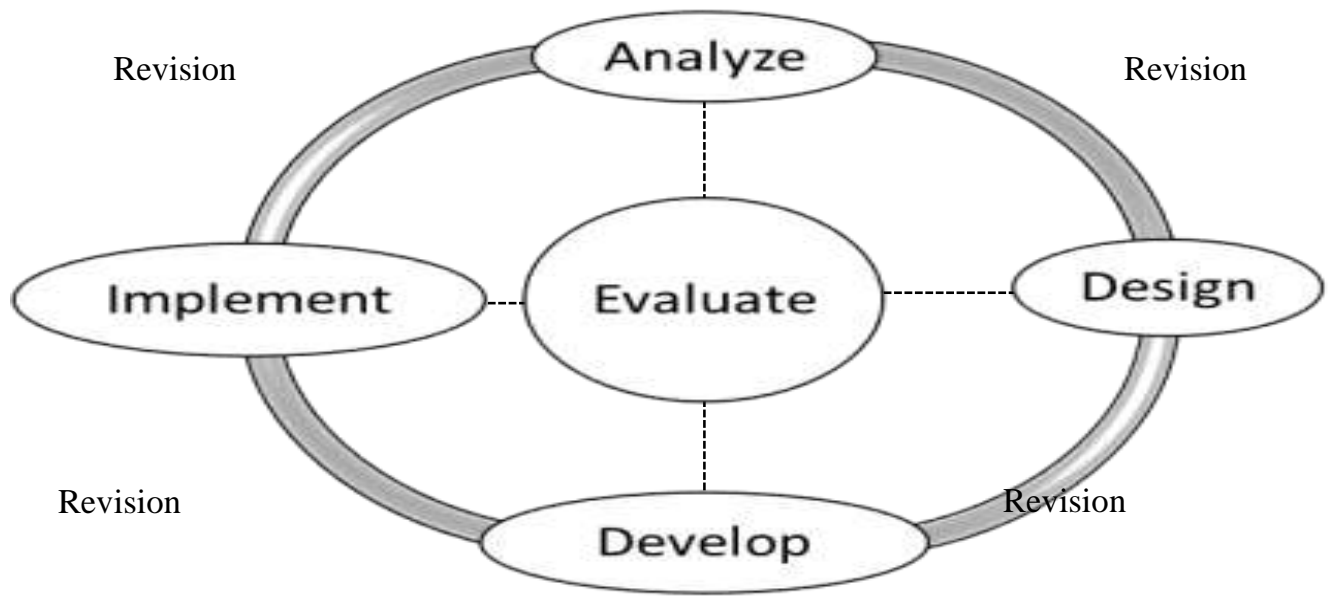

Gambar 1. Desain Penelitian Pengembangan Model ADDIE

Subjek penelitian pada penelitian ini adalah pengembangan media pembelajaran wayang papercraft untuk meningkatkan kosakata pada anak usia dini. Sedangkan, objek penelitian ini merupakan ahli media dan ahli materi pelajaran yang berjumlah 4 orang ahli. Teknik yang digunakan dalam mengumpulkan data yaitu wawancara, observasi, dan kuesioner. Observasi dan wawancara dilakukan untuk mengetahui permasalahan yang terjadi dilapangan. Kuesioner digunakan untuk mengumpulkan data dari validasi ahli materi dan media pembelajaran. Instrument yang digunakan dalam mengumpulkan data penelitian yaitu kuesioner. Adapun kisi-kisi kuesioner dari ahli materi yaitu kesesuain antara media dengan standar penguasaan koskata bagi anak, keluasaan dan kedalaman materi, cara penyajian. Kisi-kisi instrument ahli media pembelajaran yaitu fungsi dan manfaat media pembelajaran, Prinsip-prinsip media pembelajaran bagi anak, Kriteria pemilihan media pembelajaran, karakteristik media.

Dalam menguju validitas kontruksi dilakukan oleh para ahli (judgmentexperts). Metode analisis untuk menguji validitas isi menggunakan teori (Candiasa, 2011). Metode analisis validitas butir instrumen berdasarkan Contect Validity Ratio (CVR) dan Content Validity Index (CVI). Hasil validitas dikelompokkan dengan skala yang meliputi validitas isi sangat tinggi, validitas isi tinggi, validitas isi sedang, validitas isi rendah, dan validitas isi sangat rendah (Candiasa, 2011). Teknik yang digunakan untuk menganalisis data pada penelitian ini adalah analisis stastistik kualitatif dan kuantitatif. Analisis kualitatif digunakan dalam mengolah data berupa, saran, tanggapan, dan kritik. Analisis kuantitatif digunakan untuk menghitung skor yang didapatkan dari ahli materi dan media pembelajaran.

\section{Hasil dan Pembahasan}


Pengembangan media pembelajaran wayang papercraft menggunakan model penelitian pengembangan ADDIE dengan beberapa tahap yaitu: analisis, desain, pengembangan, implementasi, dan evaluasi. Prosedur yang dilakukan pada penelitian ini yaitu sebagai berikut. Pertama yaitu tahap analisis (analyze). Pada tahap ini kegiatan yang dilakukan yaitu menganalisis kebutuhan anak usia dini dan analisis media pembelajaran. Hasil analisis yaitu diperoleh data untuk merancang media pembelajaran yang sesuai dengan kebutuhan. Pada tahap ini hal utama yang dilakukan peneliti yaitu menganalisis perlu adanya pengembangan media untuk menunjang penguasaan kosakata. Dari hasil observasi dan wawancara kepada kepala sekolah diketahui adanya masalah pada media pembelajaran yang kurang variatif untuk penguasaan kosakata sehingga masih banyak anak yang tidak dapat mengembangkan beberapa aspek perkembangannya. Dengan demikian produk yang akan dikembangkan oleh penelitian diharapkan dapat memenuhi kebutuhan pembelajaran anak di gugus VI. Hasil analisis tersebut dapat dirancang dengan menggunakan media wayang papercraft untuk menambah penguasaan kosakata anak di Taman Kanak-Kanak kelompok B.

Tahap kedua yaitu perancangan (design). Pada tahap ini dilakukan perancangan media wayang papercraft yang berdasarkan analisis yang telah dilakukan. Desain pembuatan media dengan mengumpulkan gambar tokoh yang ada dalam cerita ayam dan kelinci bersaudara, kemudian memasukkan gambar satu persatu tersebut ke microsoft word untuk menyesuaikan ukuran. Ukuran yang digunakan yaitu $29 \mathrm{~cm}$ x $21 \mathrm{~cm}$ dengan 1 lembar penuh untuk 1 Gambar tokoh. Alat dan bahan yang digunakan dalam pembuatan media wayang papercraft yaitu gambar tokoh kartun, kertas karton, gunting, lem, stik kayu.
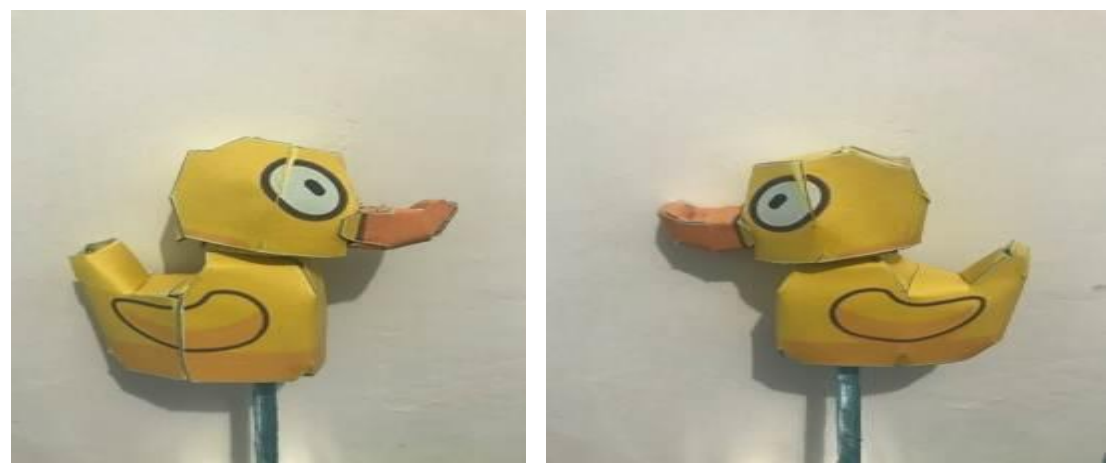

Gambar 2. Desain Media Wayang Papercraft

Tahap ketiga yaitu pengembangan (development). Pada tahap ini dilakukan pengembangan media wayang papercraft yang disesuaikan dengan rancangan yang telah dibuat sebelumnya pada tahap design. Adapun hasil pengembangan media wayang papercraft disajikan pada Gambar berikut.

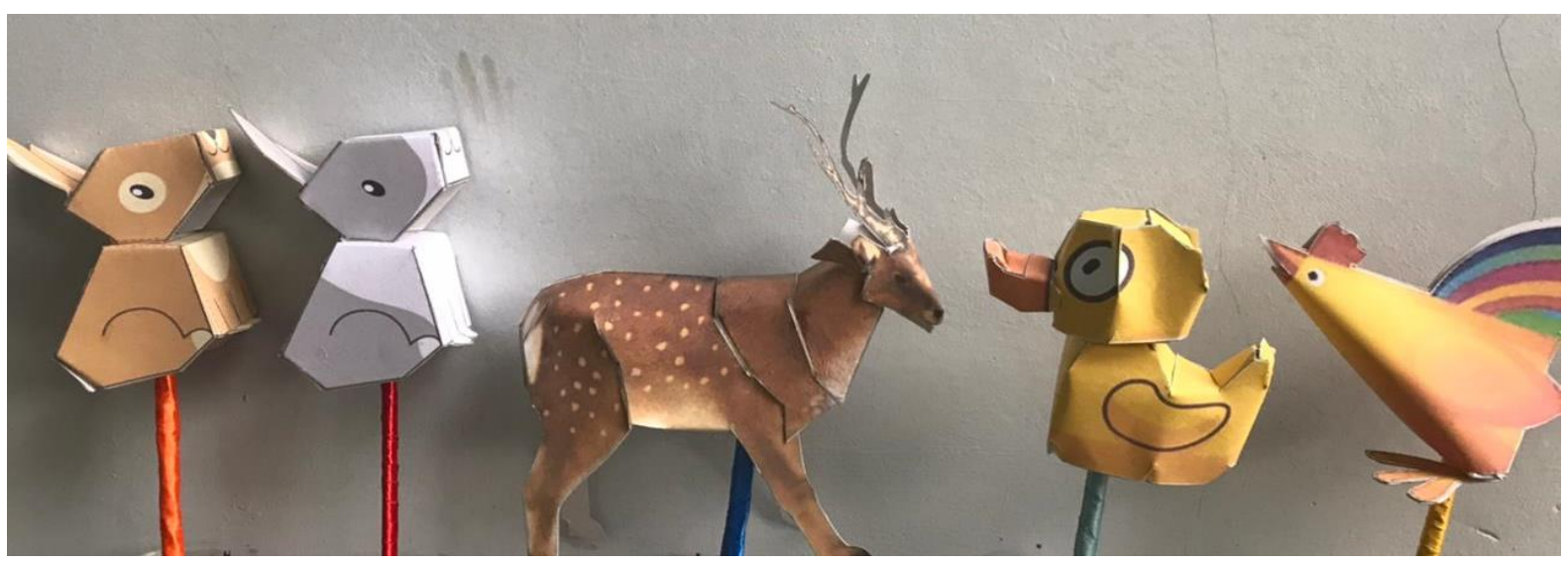

Gambar 3. Media Wayang Papercraft yang Dikembangkan

Setelah media Wayang Papercraft dikembangkan, tahap selanjutnya yaitu uji media Wayang Papercraft yang telah dikembangkan yang akan dilakukan oleh ahli materi pembelajaran dan media pembelajaran. Uji media ini dilakukan untuk mengetahui kelayakan media Wayang Papercraft yang telah dikembangkan. Hasil analisis data yang disajikan pada tabel 3, uji media Wayang Papercraft yang telah dilakukan oleh ahli materi pelajaran mendapatkan nilai 1,00 sehingga dalam kategori valid. Hasil uji ahli 
media pembelajaran mendapatkan nilai 1,00 sehingga dalam kategori valid. Dapat disimpulkan bahwa media Wayang Papercraft yang dikembangkan valid dan layak diterapkan dalam pembelajaran. Tidak ada masukan dan saran yang diberikan oleh ahli materi pelajaran dan media pembelajaran sehingga media Wayang Papercraft yang telah dikembangkan tidak perlu direvisi. Berdasarkan hasil analisis data yang telah dilakukan, dapat disimpulkan bahwa media Wayang Papercraft yang telah dikembangkan layak untuk diterapkan dalam proses pembelajaran. Media Wayang Papercraft layak diterapkan dalam proses pembelajaran, hal ini disebabkan oleh beberapa faktor yaitu sebagai berikut.

Pertama, media Wayang Papercraft layak diterapkan dalam proses pembelajaran dapat membuat anak usia dini termotivasi dan tertarik dalam belajar. Media Wayang Papercraft menarik siswa saat belajar sehingga membuat siswa termotivasi mengikuti pembelajaran di kelas. Media pembelajaran yang menarik menyebabkan siswa termotivasi dalam belajar (Devi \& Maisaroh, 2017; Hartini, Misbah, Dewantara, Oktovian, \& Aisyah, 2017; Qondias, Anu, \& Niftalia, 2016). Desain serta pemilihan warna saat mengembangkan media Wayang Papercraft ini juga sangat dipertimbangkan. Pemilihan warna yang sesuai dan menarik perhatian siswa akan meningkatkan motivasi serta semangat siswa dalam belajar (Dianawati, 2019; Mardati, Asih, \& Wangit, 2015; Nuswowati, Susilaningsih, Ramlawati, \& Kadarwati, 2017). Warna pada media disesuaikan dengan karakteristik anak, sehingga siswa lebih mudah memahami makna atau pesan yang ingin disampaikan melalui media. Selain itu penggunaan warna yang sesuai juga akan memudahkan siswa dalam mengingat gambar (Dames, Koeswanti, \& Radia, 2019; Darmayasa, Suara, \& Manuaba, 2013). Pemilihan contoh tokoh pada wayang Papercraft juga membuat siswa lebih memahami materi yang disajikan. Media yang berisikan contoh menarik akan meningkatkan semangat siswa dalam belajar (Aprinawati, 2017; Susiani et al., 2013).

Kedua, media Wayang Papercraft layak diterapkan dalam proses pembelajaran dapat membuat anak usia dini mudah memahami materi yang disampaikan oleh guru. Media Wayang Papercraft dapat merangsang daya ingat anak usia dini. Hal ini disebabkan karena tokoh yang digunakan pada media ini dapat dilihat disekitar lingkungan anak usia dini sehingga akan merangsang daya ingat anak. Media pembelajaran yang mudah dipahami akan meningkatkan daya ingat siswa (Putri, Handayani, \& Akbar, 2020; Rosnihayati, 2017; Triutami et al., 2014). Selain itu penggunaan media ini akan membantu melesatarikan kesenian wayang melalui pembelajaran. Media pembelajaran dapat berfungsi sebagai sarana yang memudahkan siswa dalam belajar sehingga siswa lebih mudah memahami materi pelajaran (Carlucy, Suadnyana, \& Negara, 2018; Tegeh, Simamora, \& Dwipayana, 2019). Media pembelajaran ini memiliki pengaruh penting hingga mempengaruhi psikologis anak seperti merangsang semangat siswa belajar. Peran media pada anak usia dini sangat penting karena saat ini anak berada pada masa berfikir konkrit sehingga anak mempelajari sesuatu yang nyata (Rahmatia, Pajarianto, Kadir, Ulpi, \& Yusuf, 2021; Solihati, 2015). Pemikiran konkrit akan dimengerti melalui benda yang dapat dirasakan secara langsung seperti media Wayang Papercraft .

Ketiga, media Wayang Papercraft layak diterapkan dalam proses pembelajaran dapat kosakata pada anak usia dini. Media Wayang Papercraft ini dipadukan dengan pembelajaran dengan aktivitas bermain sehingga juga dapat merangsang motoric anak. Temuan penelitian sebelumnya juga menyatakan bahwa aktivitas bermain adalah aktivitas yang digemari oleh anak usia dini sehingga akan memudahkan anak dalam memahami materi pembelajaran yang disajikan pada media (Rahmatia et al., 2021; Setyawati, Permanasari, \& Yuniarti, 2017; Swastrini, Antara, \& Tirtayani, 2016). Media Wayang Papercraft dapat meningkatkan kemampuan kognitif dan bahasa pada anak usia dini. Selain itu, media Wayang Papercraft ini juga mencipatkan suasana belajar yang nyaman dan menyenangkan bagi siswa. Suasana pembelajaran yang menyenangkan akan memudahkan siswa dalam menyerap sebuah informasi (Antara \& Aditya, 2019; Rani, Ardana, \& Negara, 2019; Ratna, A., Natajaya \& Dantes, 2019). Kelebihan media ini yaitu media yang dikembangkan menggunakan contoh binatang sehingga anak juga dapat belajar mengenal jenis-jenis hewan. Selain itu, media ini juga menggunakan warna yang menarik sehingga meningkatkan minat siswa dalam belajar.

Penelitian lainnya mengenai media wayang menyatakan bahwa media wayang dapat meningkatkan semangat siswa dalam belajar (Ahmadi, Rini, \& Wiratama, 2016). Temuan penelitian lainnya juga menyatakan bahwa media wayang dapat memudahkan siswa dalam memahami materi yang disampaikan oleh guru (Ahmadi et al., 2016; Kriswantoro, 2013; Putra et al., 2019). Berdasarkan temuan penelitian tersebut, dapat disimpulkan bahwa Wayang Papercraft merupakan media pembelajaran yang dapat memfasilitasi siswa dalam belajar sehingga motivasi siswa untuk belajar meningkat. Hal ini akan berdampak pada peningkatan kosakata pada anak usia dini. Implikasi penelitian ini yaitu media Wayang Papercraft yang telah dikembangkan dapat digunakan oleh guru sebagai media pembelajaran yang dapat memfasilitasi siswa dalam belajar. media ini juga dapat meningkatkan semangat siswa dalam belajar, sehingga berdampak pada pemahaman anak yang meningkat pula. Media yang dikembangkan dalam 
bentuk media wayang papercraft dapat dimanfaatkan guru untuk mempermudah proses pembelajaran khususnya dalam kegiatan penguasaan kosakata.

\section{Simpulan}

Media Wayang Papercraft yang telah dikembangkan mendapatkan kategori valid dari para ahli. Dapat disimpulkan bahwa media Wayang Papercraft layak diterapkan dalam proses pembelajaran karena memudahkan anak usia dini memahami materi pembelajaran dan berdampak pada peningkatan kosakata pada anak usia dini. Media ini dapat digunakan oleh guru untuk menciptakan suasana belajar yang menyenangkan bagi anak sehingga pemahaman anak dalam belajar akan meningkat.

\section{Daftar Rujukan}

Ahmadi, C., Rini, E. S., \& Wiratama, I. W. A. (2016). Media Pembelajaran Pengenalan Rupa Dan Karakter Tokoh Wayang Purwa Berbasis Android. Jurnal Eksplora Informatika, 4(2). Retrieved from https://eksplora.stikom-bali.ac.id/index.php/eksplora/article/view/66.

Akbar, A. (2015). Pemerolehan Morfem Afiks Bahasa Indonesia Anak Usia 2-6 Tahun Di Paud Buana Desa Banyu Urip Kabupaten Lombok Tengah. RETORIKA: Jurnal Bahasa, Sastra, Dan Pengajarannya, 1(2). https://doi.org/https://doi.org/10.22225/jr.1.2.32.250-257.

Alexander Nawangseto Mahendrapati. (2020). Visualisasi Doa Jalan Salib Mengadopsi Gaya Wayang Beber Dengan Teknik Seni Grafis Cukil Kayu. Brikolase, 11(2). https://doi.org/https://doi.org/10.33153/brikolase.v11i2.2931.

Andriyani, R., Masrul, M., \& Fauziddin, M. (2018). Pengaruh Metode Becerita terhadap Kemampuan Kosakata Anak Usia Dini. AULAD, 1(1). Retrieved from http://aulad.org/index.php/aulad/article/view/3.

Antara, \& Aditya, P. (2019). Pengaruh Model Pembelajaran Kontekstual Terhadap Kemampuan Membaca Permulaan Anak. Mimbar Ilmu, 24. https://doi.org/http://dx.doi.org/10.23887/mi.v24i2.21263.

Aprinawati, I. (2017). Penggunaan Media Gambar Seri Untuk Meningkatkan Kemampuan Berbicara Anak Usia Dini. Jurnal Obsesi: Jurnal Pendidikan Anak Usia Dini, 1(1). https://doi.org/https://doi.org/10.31004/obsesi.v1i1.33.

Arifiyanti, N., \& Ananda, K. (2018). Produksi Kosakata Anak Melalui Electronic Wordless Picture Storybook. RETORIKA, 11(2). https://doi.org/https://doi.org/10.26858/retorika.v11i2.6405.

Ayuswantana, A. C., Sachari, A., \& Irfansyah, I. (2020). Pengaruh Nilai Islam pada Visual Pakaian Dewa dan Resi Boneka Wayang Jekdong Jawa Timur. Andharupa: Jurnal Desain Komunikasi Visual \& Multimedia, 6(1). https://doi.org/https://doi.org/10.33633/andharupa.v6i1.2852.

Cahyaningrum, E. S., Sudaryanti, S., \& Purwanto, N. A. (2017). Pengembangan Nilai-Nilai Karakter Anak Usia Dini Melalui Pembiasaan Dan Keteladanan. Jurnal Pendidikan Anak, 6(2), 203-213. https://doi.org/10.21831/jpa.v6i2.17707.

Candiasa, I. M. (2011). Pengujian Instrumen Penelitian Disertai Aplikasi Iteman dan Bigsteps. Singaraja: Undiksha.

Carlucy, Suadnyana, \& Negara. (2018). Pengaruh Model Pembelajaran Inkuiri Terbimbing Berbantuan Media Konkret Terhadap Kompetensi Pengetahuan IPA. Mimbar Ilmu Undiksha, 23(2), 162-169. https://doi.org/https://doi.org/10.23887/mi.v23i2.16416.

Dames, I., Koeswanti, H. D., \& Radia, E. H. (2019). Penerapan Model Examples Non Examples Berbantuan Media Gambar Untuk Meningkatkan Hasil Belajar Pada Tema 1 Siswa Kelas 5 SDN Sidorejo Lor 05. Jurnal Basicedu, 3(1). https://doi.org/https://doi.org/10.31004/basicedu.v3i2.59.

Darihastining, S., Aini, S. N., Maisaroh, S., \& Mayasari, D. (2020). Penggunaan Media Audio Visual Berbasis Kearifan Budaya Lokal pada Anak Usia Dini. Jurnal Obsesi : Jurnal Pendidikan Anak Usia Dini, 5(2), 1594-1602. https://doi.org/10.31004/obsesi.v5i2.923.

Darmayasa, I. W. G. S., Suara, I. M., \& Manuaba, I. B. S. (2013). Penerapan Model Pembelajaran Kooperatif Tipe Two Stay Two Strayberbantuan Media Gambar Untuk Meningkatkan Motivasi Dan Hasil $\begin{array}{lllll}\text { Belajar PKn. } & \text { MIMBAR }\end{array}$ https://doi.org/http://dx.doi.org/10.23887/jjpgsd.v1i1.922.

Devi, \& Maisaroh, S. (2017). Pengembangan Media Pembelajaran Buku Pop-Up Wayang Tokoh Pandhawa Pada Mata Pelajaran Bahasa Jawa Kelas V SD. Jurnal PGSD Indonesia, 3(2), 1-16. Retrieved from http://ojs.upy.ac.id/ojs/index.php/jpi/article/view/985.

Dianawati, E. P. (2019). Pengaruh Media Tebak Gambar dan Talking Stick Terhadap Motivasi Belajar Siswa. Jurnal Ilmiah UNY, 1(1). https://doi.org/https://doi.org/10.21831/jwuny.v1i1.26855.

Fadlilah, A. N. (2020). Strategi Menghidupkan Motivasi Belajar Anak Usia Dini Selama Pandemi COVID-19 
melalui Publikasi. Jurnal Obsesi: Jurnal Pendidikan Anak Usia Dini, 5(1), 373. https://doi.org/10.31004/obsesi.v5i1.548.

Fauziddin, M. (2015). Peningkatan Kemampuan Matematika Anak Usia Dini Melalui Permainan Jam Pintar Di Taman Kanak- Kanak Pembina Kecamatan Bangkinang Kota. Jurnal Obsesi : Jurnal Pendidikan Anak Usia Dini, 1(1). https://doi.org/https://doi.org/10.31004/obsesi.v1i1.55.

Fika, Y., Meilanie, S. M., \& Fridani, L. (2020). Peningkatan Kemampuan Bicara Anak melalui Bermain Peran Berbasis Budaya. Jurnal Obsesi: Journal of Early Childhood Education, 4(1). https://doi.org/https://doi.org/10.31004/obsesi.v4i1.229.

Gunawan, G., Sahidu, H., Harjono, A., \& Suranti, N. M. Y. (2017). The effect of project based learning with virtual media assistance on student's creativity in physics. Jurnal Cakrawala Pendidikan, 1(2). https://doi.org/https://doi.org/10.21831/cp.v36i2.13514.

Hartini, S., Misbah, Dewantara, D., Oktovian, R. A., \& Aisyah, N. (2017). Developing learning media using online prezi into materials about optical equipments. Jurnal Pendidikan IPA Indonesia, 6(2), 313317. https://doi.org/10.15294/jpii.v6i2.10102.

Khadijah, K., Arlina, A., Hardianti, R. W., \& Maisarah, M. (2021). Model Pembelajaran Bank Street dan Sentra, serta Pengaruhnya terhadap Sosial Emosional Anak. Jurnal Obsesi : Jurnal Pendidikan Anak Usia Dini, 5(2). https://doi.org/https://doi.org/10.31004/obsesi.v5i2.1054.

Koesoemadinata, M. I. P. (2018). Visual Adaptation Of Wayang Characters In Teguh Santosa's Comic Art. MUDRA: Jurnal Seni Budaya, 33(3). https://doi.org/https://doi.org/10.31091/mudra.v33i3.544.

Kriswantoro, A. (2013). Pertunjukan Boneka Multi Dimensi "Sumpah Pralaya". Resital Jurnal Seni Pertunjukan, 13(2). https://doi.org/https://doi.org/10.24821/resital.v13i2.521.

Liyana, A., \& Kurniawan, M. (2019). Speaking Pyramid sebagai Media Pembelajaran Kosa Kata Bahasa Inggris Anak Usia 5-6 Tahun. Jurnal Obsesi: Jurnal Pendidikan Anak Usia Dini, 3(1). https://doi.org/10.31004/obsesi.v3i1.178.

Maqfiroh, Khutobah, \& Budyawati. (2020). Pengembangan Media MOTIF (Monopoli Edukatif) dalam Pembelajaran berbasis Multiple intelligence. Cakrawala Dini: Jurnal Pendidikan Anak Usia Dini, 11(1), 64-74. $\quad$ Retrieved from https://ejournal.upi.edu/index.php/cakrawaladini/article/view/24230/12062.

Mardati, Asih, \& Wangit. (2015). Pengembangan Media Permainan Kartu Gambar Dengan Teknik Make A Match Untuk Kelas 1 SD. Jurnal Prima Edukasia, 3(2), 120- 132. https://doi.org/https://doi.org/10.21831/jpe.v3i2.6532.

Marwiyati, S., \& Istiningsih, I. (2021). Pembelajaran Saintifik pada Anak Usia Dini dalam Pengembangan Kreativitas di Taman Kanak-Kanak. Jurnal Obsesi: Jurnal Pendidikan Anak Usia Dini, 5(1). https://doi.org/https://doi.org/10.31004/obsesi.v5i1.508.

Nababan, R. S., Guntur, Mulyana, A. R., \& Dharsono. (2016). Esensi Dan Nilai Seni Poster Pagelaran Wayang Kulit Karya Gestisutis. Gelar: Jurnal Seni Budaya, 14(1). https://doi.org/https://doi.org/10.33153/glr.v14i1.1745.

Nuswowati, M., Susilaningsih, E., Ramlawati, \& Kadarwati, S. (2017). Implementation of problem-based learning with green chemistry vision to improve creative thinking skill and students' creative actions. Jurnal Pendidikan IPA Indonesia, 6(2), 221-228. https://doi.org/10.15294/jpii.v6i2.9467.

Pebri, Tegeh, \& Rahayu. (2017). Efektivitas Metode Bercerita Dengan Media Boneka Wayang Terhadap Kemampuan Bercakap-Cakap Anak Kelompok B Di TK Widya Sesana Sangsit 2016/2017. Journal Pendidikan Anak Usia Dini Undiksha, 5(3), 336-347. https://doi.org/http://dx.doi.org/10.23887/paud.v5i1.11557.

Pebriana, P. H. (2017). Analisis Penggunaan Gadget Terhadap Kemampuan Interaksi Sosial Anak Usia Dini. Jurnal Obsesi: Journal of Early Childhood Education, 1(1). https://doi.org/https://doi.org/10.31004/obsesi.v1i1.26.

Prakarsi, E., Karsono, K., \& Dewi, N. K. (2020). Penggunaan Media Busy Book Untuk Mengembangkan Kemampuan Mengenal Pola Pada Anak Usia 4-5 Tahun. Kumara Cendikiawan, 8(2).

Puspitorini, Subali, \& Jumadi. (2014). Penggunaan Media Komik Dalam Pembelajaran IPA Untuk Meningkatkan Motivasi Dan Hasil Belajar Kognitif Dan Afektif. Cakrawala Pendidikan, 33(3), 413420. Retrieved from https://journal.uny.ac.id/index.php/cp/article/view/2385/pdf.

Putra, A. T., Handarini, D. M., \& Ramli, M. (2019). Media Wayang Golek untuk Menumbuhkan Kesadaran Menyelesaikan Konflik secara Konstruktif bagi Siswa SMP. Jurnal Pendidikan: Teori, Penelitian, Dan Pengembangan, 4(11). https://doi.org/https://doi.org/10.17977/jptpp.v4i11.13006.

Putri, D. K., Handayani, M., \& Akbar, Z. (2020). Pengaruh Media Pembelajaran dan Motivasi Diri terhadap Keterlibatan Orang Tua dalam Pendidikan Anak. Jurnal Obsesi : Jurnal Pendidikan Anak Usia Dini, 4(2). https://doi.org/https://doi.org/10.31004/obsesi.v4i2.418.

Putri, L. A. D., Yetti, E., \& Hartati, S. (2020). Pengaruh Keterlibatan Orangtua dan Regulasi Diri terhadap 
Perilaku Bullying Anak Usia Dini. Jurnal Obsesi: Jurnal Pendidikan Anak Usia Dini, 4(2). https://doi.org/https://doi.org/10.31004/obsesi.v4i2.438.

Qondias, Anu, \& Niftalia. (2016). Pengembangan Media Pembelajaran Tematik Berbasis Mind Mapping SD Kabupaten Ngada Flores. Jurnal Pendidikan Indonesia, 5(2), 176--182. https://doi.org/http://dx.doi.org/10.23887/jpi-undiksha.v5i2.8590.

Rahmatia, R., Pajarianto, H., Kadir, A., Ulpi, W., \& Yusuf, M. (2021). Pengembangan Model Bermain Konstruktif dengan Media Balok untuk Meningkatkan Visual-Spasial Anak. Jurnal Obsesi : Jurnal Pendidikan Anak Usia Dini, 6(1). https://doi.org/https://doi.org/10.31004/obsesi.v6i1.1185.

Rani, Ardana, \& Negara. (2019). Pengaruh Model Pembelajaran Talking Stick Berbantuan Lagu Tradisional Terhadap Kompetensi Pengetahuan IPA. Jurnal Mimbar Ilmu, 24(3). https://doi.org/http://dx.doi.org/10.23887/mi.v24i3.21676.

Ratna, A., Natajaya, I. N., \& Dantes, K. R. (2019). Determinasi Servant Leadership, Karakteristik Individu, Motivasi Kerja, dan Kepuasan Kerja Terhadap Komitmen Guru Di SMAN 1 Gianyar. Jurnal Administrasi Pendidikan Indonesia, 10(2), 119-124. https://doi.org/10.23887/japi.v10i2.2798.

Rosalina, A., Widyasari, Y., Ismi, M., \& Hapsari. (2010). Peranan Orangtua Dalam Dongeng Sebelum Tidur Untuk Optimalisasi Kemampuan Berkomunikasi Anak Usia Dini. PSYCHO IDEA, 8(2). https://doi.org/https://doi.org/10.30595/psychoidea.v8i2.236.

Rosnihayati. (2017). Penggunaan Media Gambar untuk Meningkatkan Hasil Belajar IPS Siswa Kelas II SDN 003 Pagaran Tapah Darussalam Kabupaten Rokan Hulu. Primary: Jurnal Pendidikan Guru Sekolah Dasar, 6(1), 306-313. $\quad$ Retrieved from https://primary.ejournal.unri.ac.id/index.php/JPFKIP/article/view/4110/3984.

Ruiyat, S. A., Yufiarti, Y., \& Karnadi, K. (2019a). Peningkatan Keterampilan Berbicara dengan Bercerita Menggunakan Komik Elektronik Tematik. Jurnal Obsesi : Journal of Early Childhood Education, 3(2). https://doi.org/https://doi.org/10.31004/obsesi.v3i2.256.

Ruiyat, Yufiarti, \& Karnadi. (2019b). Peningkatan Keterampilan Berbicara dengan Bercerita Menggunakan Komik Elektronik Tematik. Jurnal Obsesi: Urnal Pendidikan Anak Usia Dini DOI, 3(2), 518-526. https://doi.org/10.31004/obsesi.v3i2.256.

Salamah, E. R. (2017). Penggunaan Media Wayang Pada Pembelajaran Ips Materi Tokoh Tokoh Kemerdekaan Indonesia Untuk Meningkatkan Hasil Belajar Siswa Kelas V Sekolah Dasar. METODIK DIDAKTIK, 12(2).

Setyawati, Permanasari, \& Yuniarti. (2017). Meningkatkan Kecerdasan Musikal Melalui Bermain Alat Musik Angklung (Penelitian Tindakan Pada Anak Kelompok B Usia 5-6 Tahun Di TK Negeri Pembina Kota Serang-Banten). JPKS (Jurnal Pendidikan Dan Kajian Seni), 2(1). https: //doi.org/http://dx.doi.org/10.30870/jpks.v2i1.2503.

Solihati, S. (2015). Efektifitas Media Panggung Boneka untuk Meningkatkan Kemampuan Bercerita pada Anak Usia Dini. Modeling: Jurnal Program Studi PGMI, 2(2). https://doi.org/https://doi.org/10.2345/modeling.v2i2.2176.

Suardi, I. P., Ramadhan, S., \& Asri, Y. (2019). Pemerolehan Bahasa Pertama pada Anak Usia Dini. Jurnal Obsesi : Journal of Early Childhood https://doi.org/https://doi.org/10.31004/obsesi.v3i1.160.

Sunismi. (2015). Developing Guided Discovery Learning Materials Using Mathematics Mobile Learning Application As An Alternative Media For The Students Calculus II. Cakrawala Pendidikan, 34(5). https: //doi.org/https://doi.org/10.21831/cp.v3i3.7340.

Suprihatin, E. W., \& Pratamawati, D. (2019). Conservation Strategy in Preserving The Local Image Existence of Wayang Topeng. Harmonia: Journal of Arts Research And Education, 19(2). https://doi.org/https://doi.org/10.15294/harmonia.v19i2.24005.

Susiani, P. E., Pudjawan, K., \& Renda, N. T. (2013). Penerapan Metode Role Playing Berbantuan Media Boneka Gambar Untuk Meningkatkan Kemampuan Bahasa Indonesia Anak Kelompok B TK Satya Kumara. Jurnal Pendidikan Anak Usia Dini Undiksha, 1(1). https: //doi.org/http://dx.doi.org/10.23887/paud.v1i1.1138.

Suswandari, M. (2019). Penerapan Model Induktif Berbantuan Media Wayang Suket pada Siswa Sekolah Dasar. QALAMUNA, 10(2). https://doi.org/https://doi.org/10.5281/zenodo.3559255.

Suwatra, Magta, \& Christiani. (2019). Pengaruh Media Busy Book Terhadap Kemampuan Problem Solving Anak Kelompok A Taman Kanak-Kanak. Mimbar Ilmu Undiksha, 24(2), 185-193. https://doi.org/http://dx.doi.org/10.23887/mi.v24i2.21257.

Swastrini, Antara, P. A., \& Tirtayani, L. A. (2016). Penerapan Bermain Ular Tangga Untuk Meningkatkan Kemampuan Kerjasama Kelompok B1 di TK Widya Sesana Sangsit. Pendidikan Anak Usia Dini, 4(2). https://doi.org/http://dx.doi.org/10.23887/paud.v4i2.7764.

Tegeh, I. M., \& Kirna, I. M. (2010). Metode Penelitian Pengembangan Pendidikan. Singaraja: Undiksha. 
Tegeh, Simamora, \& Dwipayana. (2019). Pengembangan Media Video Pembelajaran Dengan Model Pengembangan 4D Pada Mata Pelajaran Agama Hindu. Mimbar Ilmu Undiksha, 24(2), 158-166. https: //doi.org/http://dx.doi.org/10.23887/mi.v24i2.21262.

Trisnanti, I. A. N. L., Tirtayani, L. A., \& Putra, I. K. A. (2018). Pengaruh Media Flashcard Bilingual Terhadap Kemampuan Kosakata Bahasa Inggris Permulaan Anak Kelompok B TK Gugus Mawa. Journal $\begin{array}{lllll}\text { Pendidikan Anak Usia Uini } & \end{array}$ https://doi.org/http://dx.doi.org/10.23887/paud.v6i1.15200.

Triutami, I. G. A. A. D., Sudhita, I. W. R., \& Tegeh, I. M. (2014). Penerapan Metode Bercerita Berbantuan Media Boneka Tangan Untuk Meningkatkan Perkembangan Bahasa Pada Anak. Jurnal Pendidikan Anak Usia Dini, 2(1). https://doi.org/http://dx.doi.org/10.23887/paud.v2i1.3239.

Utomo, I. A., Ramli, M., \& Furaidah, F. (2018). Penerapan Strategi Bermain melalui Media Busy Book untuk Meningkatkan Fisik Motorik Halus Anak Usia Dini. Jurnal Pendidikan: Teori, Penelitian, Dan Pengembangan, 3(12). https://doi.org/https://doi.org/10.17977/jptpp.v3i12.12553.

Yuliani, Antara, \& Magta. (2017). Pengaruh Video Pembelajaran Terhadap Kemampuan Berhitung Permulaan Anak Kelompok B Di Taman Kanak-Kanak. Jurnal Pendidikan Anak Usia Undiksha, 5(1), 96-106. https://doi.org/http://dx.doi.org/10.23887/paud.v5i1.11309.

Yuniarni, D. (2021). Pengembangan Busy Book Berbasis Neurosains dalam Rangka Pengenalan Seks untuk Anak Usia Dini. Jurnal Obsesi : Journal of Early Childhood Education, 6(1). https://doi.org/https://doi.org/10.31004/obsesi.v6i1.1336.

Zeptyani, \& Wiarta. (2020). Pengaruh Project-Based Outdoor Learning Activity Menggunakan Media Audio Visual Terhadap Perilaku Belajar Anak Usia Dini. Jurnal Pendidikan Anak Usia Dini Undiksha, 8(2), 69-79. https://doi.org/http://dx.doi.org/10.23887/paud.v8i2.24740. 